\title{
MORPHOLOGICAL, MORPHOMETRIC AND MOLECULAR CHARACTERIZATION OF MERLINIUS MICRODORUS (GERAERT, 1966) SIDDIQI, 1970, SCUTYLENCHUS RUGOSUS (SIDDIQI, 1963) SIDDIQI, 1979 (MERLINIIDAE), AND PSILENCHUS CURCUMERUS RAHAMAN, AHMAD AND JAIRAJPURI, 1994 (PSILENCHIDAE) AND APPROACHES TO PHYLOGENETIC RELATIONSHIPS
}

\author{
(*) Department of Plant Protection, College of Agriculture, Ferdowsi University of Mashhad, P.O. Box 91775-1163, \\ Mashhad, Iran. \\ (**) Department of Agronomy and Plant Breeding, College of Agriculture, Shahid Chamran University of Ahvaz, P.O. \\ Box 61357-83151, Ahvaz, Iran \\ Corresponding author: Esmat Mahdikhani-Moghadam, e-mail mahdikhani-e@ferdowsi.um.ac.ir
}

Azimi S., Mahdikhani Moghadam E., Rouhani H., Rajabi Memari H. - Morphological, morphometric and molecular characterization of Merlinius microdorus (Geraert, 1966) Siddiqi, 1970, Scutylenchus rugosus (Siddiqi, 1963) Siddiqi, 1979 (Merliniidae), and Psilenchus curcumerus Rahaman, Ahmad and Jairajpuri, 1994 (Psilenchidae) and approaches to phylogenetic relationships.

Merlinius microdorus and Scutylenchus rugosus (Merliniidae), and Psilenchus curcumerus (Psilenchidae) were collected from the rhizosphere of faba bean (Vicia faba L.) fields in Khuzestan province, south-western Iran. Morphological and morphometric data are provided for these species. Additionally, sequences of the D2-D3 expansion segments of $28 \mathrm{~S}$ rRNA gene for all species were also used for molecular phylogenetic analysis. The phylogenetic relationships of Psilenchidae and Merliniidae in relation to representatives of the superfamily Tylenchoidea, obtained from Bayesian inference (BI) and maximum likelihood (ML) analyses of the D2-D3 sequences, are presented and discussed. The results of phylogenetic analysis strongly supported $(\mathrm{BPP}=100)$ Merliniidae and Psilenchidae as monophyletic. The family Tylenchidae formed a sister clade to Merliniidae/Psilenchidae with high branch support $(\mathrm{BPP}=100)$. Monophyly of representatives of Merliniidae (including Pratylenchoides) was supported with maximum BPP.

Key Words: 28S rRNA gene, Merlinius, phylogeny, Psilenchus, Scutylenchus.

\section{INTRODUCTION}

The genus Psilenchus was erected by De man, 1921, with $P$. hilarulus as the type species. On the basis of evolutionary trends, Paramonov, 1970, proposed that Tylenchida Thorne, 1949 has evolved from fungus-feeding ancestors and suggested a hypothetical ancestor close to the modern Psilenchus (SubBotin et al., 2006). SidDiQI (1986) considered Psilenchus under the family Psilenchidae (Paramonov, 1967) Khan, 1969 in the Dolichodoroidea Chitwood in Chitwood \& Chitwood, 1950. LuC et al. (1987) also suggested that Psilenchus appears closer to Tylenchina Chitwood in Chitwood \& Chitwood, 1950 ancestors. GERAERT \& RASKI (1987) did not consider the paired female reproductive system (i.e. didelphic) as a character of sufficient merit to sustain a separate subfamily and synonymised the proposed Psilenchinae with Boleodorinae, under Tylenchidae (Geraert, 2008). MAGgenti et al. (1987) also placed Psilenchus in Boleodorinae. CHIZHOV and BEREZINA (1988) studied the female reproductive system of Tylenchida and proposed Psilenchus as the most primitive tylenchid form, with many ancestral morphological characters including large postlabial amphidial apertures, a weak stylet, didelphic reproductive system and presence of phasmids (SIDDIQI, 2000).

RYSS (1993) analysed the phylogeny of the order
Tylenchida using complex of morphological characters (amphids, phasmids, deirids, lateral field and head sensory organs) and suggested that only a few genera have a complete set of the lateral complex structures: Antarctenchus, Atetylenchus and Psilenchus in Psilenchidae, and genera belonging to the family Merliniidae Siddiqi, 1971: Merlinius, Amplimerlinius, Nagelus, Geocenamus and Pratylenchoides. The author also suggested that Atetylenchus and Psilenchus, which have the amphids situated posteriorly in the cephalic region may represent the most primitive forms in the order Tylenchida.

StURHAN \& RAHi (1996) also placed the genera Psilenchus, Atetylenchus and Antarctenchus in Psilenchidae under Dolichodoroidea following Siddiqi (1986) and Ryss (1993). SidDiQI (2000) believed that Psilenchus-like forms might be regarded as ancestors of Hoplolaimina, but not Tylenchina, Criconematina, and Hexatylina. BERT et al. (2006) studied the comparative cellular architecture of the female gonoduct among Tylenchoidea and believed that the absence of a clear quadricolumella, or tricolumella was insufficient to properly assign the genus Psilenchus to either Tylenchidae or Dolichodoroidea. GERAERT (2008) considered the genus Psilenchus under the Boleodorinae and listed 21 valid species.

Phylogenetic analyses using 28S r DNA sequences, showed Psilenchus as a sister taxon with Amplimerlinius and Nagelus (SUBBOTIN et al., 2006; PALOMARES-Rius et al., 
2009; CARTA et al., 2010; GHADERI et al., 2014b). On the other hand, phylogenetic studies using $18 \mathrm{~S}$ rDNA sequences (Holterman et al., 2006, 2009), showed Psilenchus to be unresolved. BERT et al. (2008) indicated that monodelphic nature of female reproductive system is ancestral for tylenchid nematodes, and thus considered Psilenchus as a non-primitive tylenchid taxon and different phylogenetic position of Psilenchus was found being related to the used method of inferring the phylogenetic trees. Likewise, the position of Psilenchus in PALOMARES-RIUS et al. (2009), also based on the 18S rDNA, is not resolved. CARTA et al. (2010) selected $P$. hilarulus as an outgroup taxon for their molecular phylogenetic study of Merliniidae/Pratylenchoides, disregarding representatives of Tylenchidae, and therefore, the relationships between Tylenchidae, Psilenchidae and Merliniidae were not resolved.

The present study aims to characterize species of genera Merlinius, Psilenchus and Scutylenchus collected from faba bean fields in Iran using morphological and molecular data. Additionally, the phylogenetic relationships of Psilenchidae and Merliniidae are evaluated on the basis of the D2-D3 expansion segments of the 28S rRNA gene.

\section{MATERIALS AND METHODS}

\section{NEMATOdE SAMPLES}

Soil samples were collected during 2012-2014 from the rhizosphere of faba bean (Vicia faba L.) fields in Khuzestan Province, south-western Iran. Nematodes were extracted from soil samples with rapid centrifugal flotation technique (JENKINS, 1964). For morphological characterization and morphometric measurements, nematodes were killed in hot $4 \%$ formaldehyde solution and transferred to anhydrous glycerin (DE GRISSE, 1969). Specimens were then transferred to pure glycerin and mounted on permanent slides. Observations and measurements were performed using a Leitz SM-LUX light microscope equipped with a drawing tube. The best-preserved specimens were also photographed using an Olympus DP72 digital camera attached to an Olympus BX51 light microscope. Nematode species were identified based on morphological and morphometric characters (GERAERT, 2008; GERAERT, 2011).

\section{DNA EXTRACTING, PCR AND SEQUENCING}

For molecular analyses, a single female of each species was picked out from samples, examined in drop of distilled water on a temporary slide under the light microscope, transferred to $7 \mu \mathrm{l}$ of AE buffer ( $10 \mathrm{mM}$ Tris-Cl, $0.5 \mathrm{mM}$ EDTA; $\mathrm{pH}$ 9.0) on a clean slide, and then crushed using a cover slip. The suspension was collected by adding $20 \mu \mathrm{l}$ AE buffer. Each DNA sample was stored at $-20^{\circ} \mathrm{C}$ until used as a PCR template (PEDRAM et al., 2011). The D2-D3 expansion segments of the 28S rDNA was amplified using the forward D2A (5'-ACAAGTACCGTGAGGGAAAGTTG-3') and reverse D3B (5'-TCGGAAGGAACCAGCTACTA-3') primers (NUNN, 1992). PCR reactions of $25 \mu \mathrm{l}$ were made with $14 \mu \mathrm{l}$ of distilled water, $2.5 \mu \mathrm{l}$ of $10 \times$ PCR buffer, 0.5 $\mu \mathrm{l}$ of dNTP mixture, $1.5 \mu \mathrm{l}$ of $50 \mathrm{mM} \mathrm{MgCl} 2,1 \mu \mathrm{l}$ of each primer $(10 \mathrm{pmol} / \mu \mathrm{l}), 0.5 \mu \mathrm{l}$ of Taq polymerase (CinnaGen, Tehran, Iran, c. $5 \mathrm{U} / \mu \mathrm{l})$, and $4 \mu \mathrm{l}$ of DNA template. The thermal cycling program was as follows: initial denaturation at $95^{\circ} \mathrm{C}$ for $6 \mathrm{~min}$, followed by 35 cycles of denaturation at $94^{\circ} \mathrm{C}$ for $30 \mathrm{~s}$, annealing at $55^{\circ} \mathrm{C}$ for $30 \mathrm{~s}$ and extension at $72^{\circ} \mathrm{C}$ for $1 \mathrm{~min}$. A final extension was performed at $72^{\circ} \mathrm{C}$ for 10 min (PEDRAM et al., 2011). Amplification success was evaluated electrophoretically on $1 \%$ agarose gel. The PCR products were purified using the QIAquick PCR purification kit (Qiagen $\left.{ }^{\circledR}\right)$ following the manufacturer's protocol and sequenced directly using the PCR primers with an ABI 3730XL sequencer (Bioneer Corporation, South Korea). Sequences of nematode isolates were deposited in GenBank under accession numbers.

\section{PhYLOGENETIC ANALYSES}

The newly obtained sequences of the D2-D3 fragments of $28 \mathrm{~S}$ rDNA and additional sequences of relevant taxa selected after a BlastN search, were aligned by Clustal X2 (http://www.clustal.org/) using the default parameters. The outgroup taxon was chosen according to a previous study (SUBBOTIN et al., 2006). Model of base substitution was selected using MrModeltest 2 (NYLANDER, 2004) and based on the Akaike criteria. A general time reversible model, including among-site rate heterogeneity and estimates of invariant sites $(\mathrm{GTR}+\mathrm{G}+\mathrm{I})$, was selected for the phylogenetic analyses. Bayesian analysis was used to infer the phylogenetic tree using MrBayes v3.1.2 (RonQuIST \& HuELSENBECK, 2003), running the chain for one million generations. After discarding burn-in samples and evaluating convergence, the remaining samples were retained for further analyses. The Markov chain Monte Carlo (MCMC) method within a Bayesian framework was used to determine equilibrium distribution and estimate the posterior probabilities of the phylogenetic tree (LARGET \& SimON, 1999) using the 50\% majority rule. A maximum likelihood (ML) analysis was performed using the software raxmlGUI version 1.1 (Silvestro \& MichalaK, 2012). Bayesian posterior probability (BPP) and ML bootstrap (BS) values higher than $50 \%$ were given on appropriate clades. The output files of the phylogenetic programs were visualised using Dendroscope V.3.2.8 (Huson \& SCORNAVACCA, 2012) and re-drawn in CorelDRAW software version 12 .

\section{RESULTS}

Based on morphological and molecular analyses, three species of tylenchid nematodes were identified: Merlinius microdorus (Geraert, 1966) Siddiqi, 1970, [Syn: Geocenamus microdorus (Geraert, 1966) Brzeski, 1991] Scutylenchus rugosus (Siddiqi, 1963) Siddiqi, 1979, [Syn: Geocenamus rugosus (Siddiqi, 1963) Brzeski, 1991] and Psilenchus curcumerus Rahaman, Ahmad and Jairajpuri, 1994.

\section{MORPHOLOGICAL CHARACTERISATIONS}

Merlinius microdorus (Geraert, 1966) Siddiqi, 1970 (Figs I and II)

Measurements: Table 1.

\section{DESCRIPTION}

FEMALE - Body ventrally curved after fixation. Cuticle annuli 0.7-1.4 $\mu \mathrm{m}$ wide at mid-body. Lateral field with 6 incisures, often additional faint lines may appear between these. Head anteriorly somewhat rounded, usually separated by shallow depression, sometimes continuous, bearing 6 fine annuli; cephalic framework weakly or not refractive. Stylet delicate, knobs small, rounded. Dorsal pharyngeal gland orifice located at 1.5-3.3 $\mu \mathrm{m}$ behind stylet knobs. Median bulb ovale. Secretory-excretory pore at level of anterior end of basal bulb. Basal bulb pyriform, 27-33 $\mu \mathrm{m}$ long and 11-15 $\mu \mathrm{m}$ wide. Ovaries outstretched, well 
Fig. I - Merlinius microdorus. Female. 1. Entire body; 2: Vulval region showing spermatheca; 3. Anterior end; 4. Lateral field at mid-body; 5, 6. Tail showing phasmid; 7 . Tail of male.

Fig. II - Merlinius microdorus. Female. 1, 2. Anterior end; 3. Lateral field at mid-body; 4. Vulval region; 5. Tail; Male. 6. Tail. (Scale bars $=10 \mu \mathrm{m}$ )
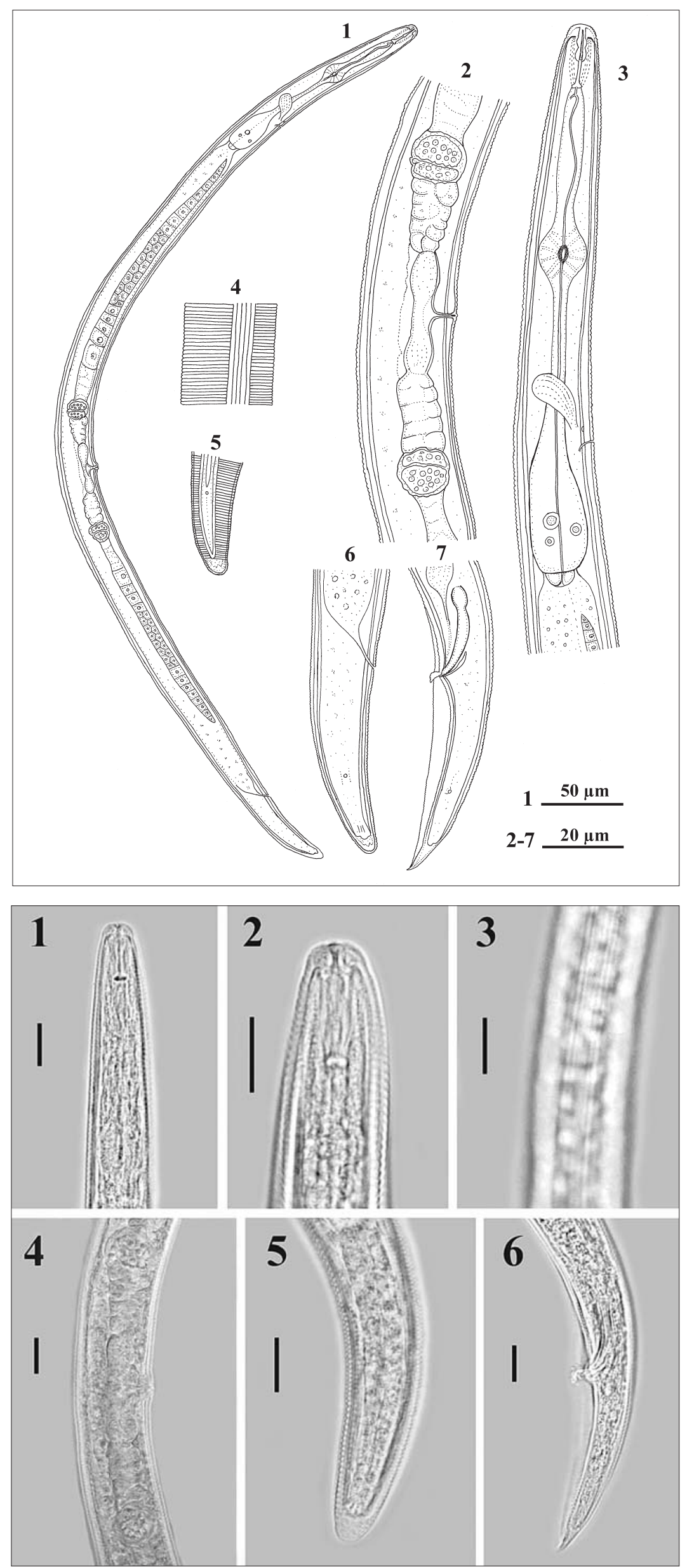
Table 1 - Morphometrics of Merlinius microdorus and Scutylenchus rugosus collected from Iran.

\begin{tabular}{|c|c|c|c|}
\hline \multirow{2}{*}{$\begin{array}{c}\text { Scutylenchus rugosus } \\
\text { Female }\end{array}$} & \multicolumn{2}{|c|}{ Merlinius microdorus } & \multirow[t]{2}{*}{ Character } \\
\hline & Male & Female & \\
\hline 20 & 12 & 15 & $\mathrm{n}$ \\
\hline $786.4 \pm 64.1(619-886.8)$ & $636.0 \pm 44.6(567.5-696.7)$ & $624.4 \pm 36.3(567.0-777.2)$ & $\mathrm{L}$ \\
\hline $34.6 \pm 4.2(31.2-41.2)$ & $33.8 \pm 2.7(29.4-37.0)$ & $29.2 \pm 3.5(24.1-34.8)$ & $\mathrm{a}$ \\
\hline $5.0 \pm 0.3(4.4-5.5)$ & $4.8 \pm 0.3(4.2-5.2)$ & $4.9 \pm 0.5(4.0-5.7)$ & $\mathrm{b}$ \\
\hline $15.5 \pm 0.8(13.5-17.1)$ & $11.5 \pm 0.7(10.4-12.6)$ & $11.7 \pm 1.3(9.9-13.4)$ & $\mathrm{c}$ \\
\hline $3.1 \pm 0.2(2.7-3.3)$ & $3.5 \pm 0.3(2.9-3.8)$ & $3.6 \pm 0.4(2.8-4.6)$ & $\mathrm{c}^{\prime}$ \\
\hline $56.2 \pm 0.9(54.7-57.9)$ & - & $56.1 \pm 3.4(49.8-59.6)$ & $\mathrm{V}$ \\
\hline $60.2 \pm 0.9(58.8-62.2)$ & - & $60.7 \pm 3.5(55.1-66.2)$ & $\mathrm{V}^{\prime}$ \\
\hline $21.8 \pm 0.9(19.2-23.3)$ & $14.3 \pm 0.6(12.7-15.2)$ & $14.3 \pm 1.1(13.0-16.4)$ & Stylet length \\
\hline $54.0 \pm 1.9(51.2-57.8)$ & $57.2 \pm 4.1(46.6-66.6)$ & $55.2 \pm 2.6(52.0-59.2)$ & $\mathrm{m}$ \\
\hline $3.2 \pm 0.7(2.0-4.0)$ & $2.1 \pm 0.4(1.5-2.5)$ & $2.3 \pm 0.7(1.5-3.3)$ & DGO \\
\hline $44.6 \pm 1.1(41.7-49.4)$ & $44.9 \pm 3.7(38.4-49.9)$ & $44.3 \pm 1.4(40.0-48.1)$ & $\mathrm{MB}$ \\
\hline $22.5 \pm 2.5(19.3-25.9)$ & $18.5 \pm 1.4(16.9-21.2)$ & $22 \pm 1.9(19.3-24.7)$ & Body width \\
\hline $123.4 \pm 5.6(108.7-142.6)$ & $103.2 \pm 11.5(92.8-123.5)$ & $102.6 \pm 6.5(93.4-115.7)$ & S. E. pore \\
\hline $23.0 \pm 1.4(19.3-27.1)$ & - & $22.2 \pm 3.2(18.3-27.2)$ & Vulval body width \\
\hline $16.6 \pm 0.9(14.7-19.2)$ & $14.8 \pm 1.7(12.7-17.8)$ & $14.5 \pm 2.8(12.2-20.6)$ & Anal body width \\
\hline $51.3 \pm 3.0(42.6-57.8)$ & $52.9 \pm 7.0(43.1-62.9)$ & $53.6 \pm 4.6(45.7-60.9)$ & Tail length \\
\hline - & $21 \pm 3.0(17.2-24.9)$ & - & Spicule length \\
\hline- & $8.4 \pm 1.7(6.6-11.8)$ & - & Gubernaculum length \\
\hline- & $67.3 \pm 15.9(53.3-90.3)$ & - & Bursa length \\
\hline $29.0 \pm 2.6(23.0-35.0)$ & - & $49.1 \pm 8.0(41.0-64.0)$ & Tail annuli \\
\hline
\end{tabular}

All measurements are in $\mu \mathrm{m}$ and in the form: mean \pm s.d. (range).

developed. Vulval cavity and epiptygma small. Spermatheca bilobed, with small rounded sperm. Tail mostly bent ventrally, narrowing to a rounded terminus, tail terminus usually smooth, sometimes variably striated; 41-64 tail annuli. Phasmids small, located in the posterior half of tail, sometimes near middle of tail.

Male - Similar to female in general view. Tail conoid and pointed, spicules arcuate, bursa enveloping tail tip, with finely crenate margins.

Scutylenchus rugosus (Siddiqi, 1963) Siddiqi, 1979 (Figs III and IV)

Measurements: Table 1.

\section{DESCRIPTION}

Female - Body ventrally curved after fixation. Cuticle annuli rounded, distinct, 1.8-2.6 $\mu \mathrm{m}$ wide at mid-body; cuticle with 31-33 longitudinal striae. Lateral fields with 6 lines, the outer bands areolated along entire body length. Cephalic region bearing 5-6 fine annuli, continuous to slightly offset from body; cephalic framework not refractive. Stylet strong, knobs rounded, slightly posteriorly directed. Dorsal gland orifice at $2-4 \mu \mathrm{m}$ behind to stylet knobs. Median bulb ovale, basal bulb elongated, 33-38 $\mu \mathrm{m}$ long and 12-16 $\mu \mathrm{m}$ wide. Ovaries outstretched, well developed; vagina swollen near vulva; epiptygma present; spermatheca without sperm, offset. Tail tapers slightly, almost cylindrical, with 23-35 annuli, non-annulated terminus; hyaline portion 3-4 $\mu \mathrm{m}$ long. Phasmids distinct, located slightly anterior to middle of tail length.

Male - Not found.

\author{
Psilenchus curcumerus Rahaman, \\ Ahmad and Jairajpuri, 1994 \\ (Figs $\mathrm{V}$ and VI) \\ Measurements: Table 2.
}

\section{DESCRIPTION}

FEMALE - Body slender, strongly ventrally curved. Cuticle finely striated, striae less than $1 \mu \mathrm{m}$ wide at midbody. Lateral fields about one-third of body width, composed of four incisures, the outer ones crenate. Lip region rounded, continuous, smooth, 6.5-7.5 $\mu \mathrm{m}$ wide and 4-5 $\mu \mathrm{m}$ high. Amphidial apertures oblique slits. Stylet delicate, without knobs. Dorsal gland orifice at 5.3-7.2 $\mu \mathrm{m}$ behind to stylet knobs. Median bulb oval, 16-18 $\mu \mathrm{m}$ long and 10-13 $\mu \mathrm{m}$ wide, muscular with prominent valvular apparatus in the middle. Basal bulb pyriform, offset, 19-24 $\mu \mathrm{m}$ long. Excretory pore almost near middle of isthmus or slightly posterior. Hemizonid two or three annuli above excretory pore. Vulval opening a transverse slit. Ovaries paired, outstretched in opposite directions. Spermatheca oval, 22-26 $\mu \mathrm{m}$ long and 12-15 $\mu \mathrm{m}$ wide, axial and filled with rounded sperm. Post-rectal sac 8-15 $\mu \mathrm{m}$ long, extending behind the anus. Tail elongate, filiform with clavate terminus.

MALE - General morphology similar to that of female except for character states associated with sexual differences. Spicules tylenchoid, ventrally curved. Gubernaculum trough-shaped. Bursa with finely crenate margins.

\section{MOLECULAR CHARACTERISATIONS}

The alignment of the D2-D3 expansion fragments of 28S rRNA gene sequences of 49 taxa (including one 


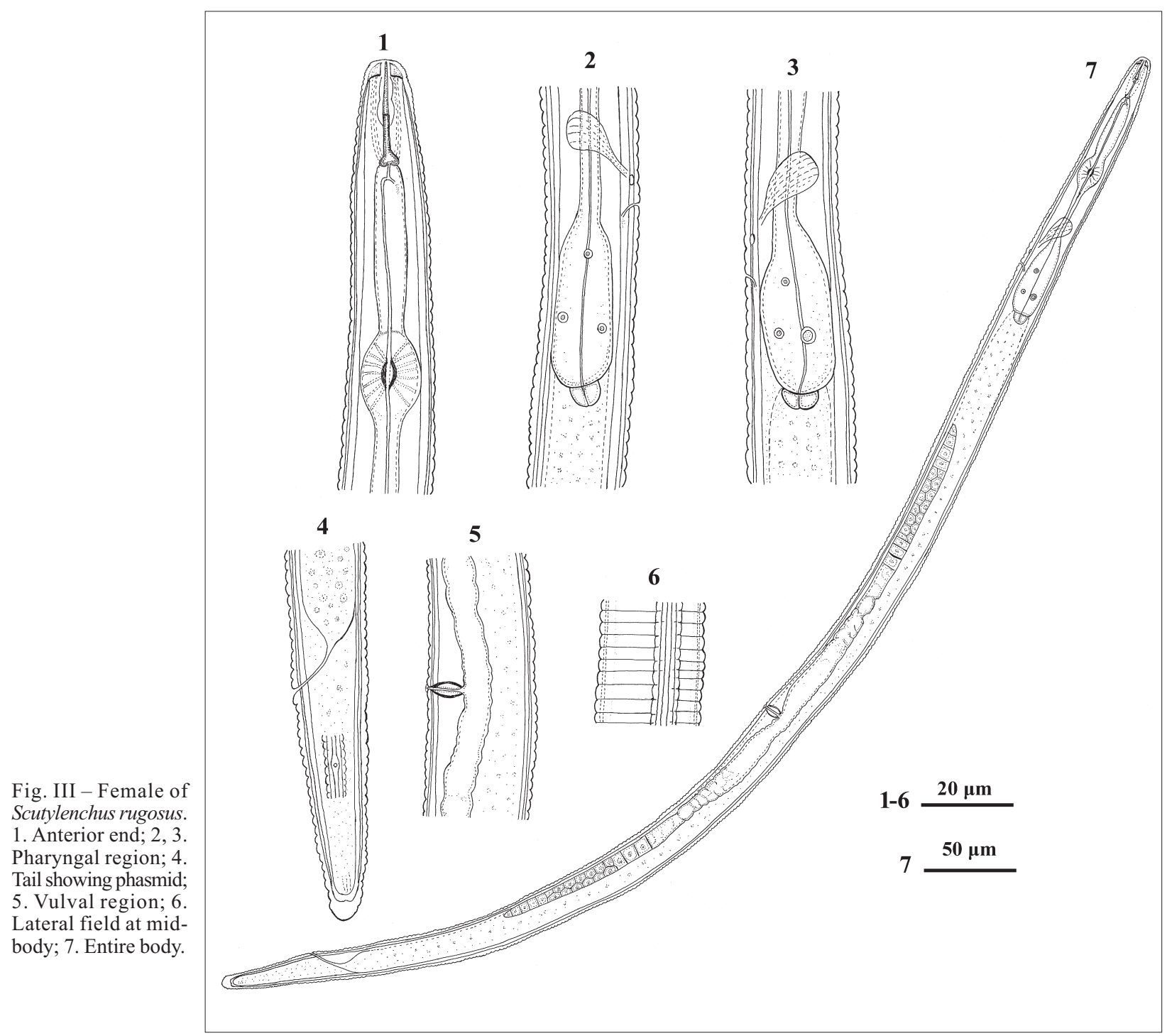

Fig. III - Female of . Pharyngal region; 4 showing phasmic Lateral field at midbody; 7. Entire body.
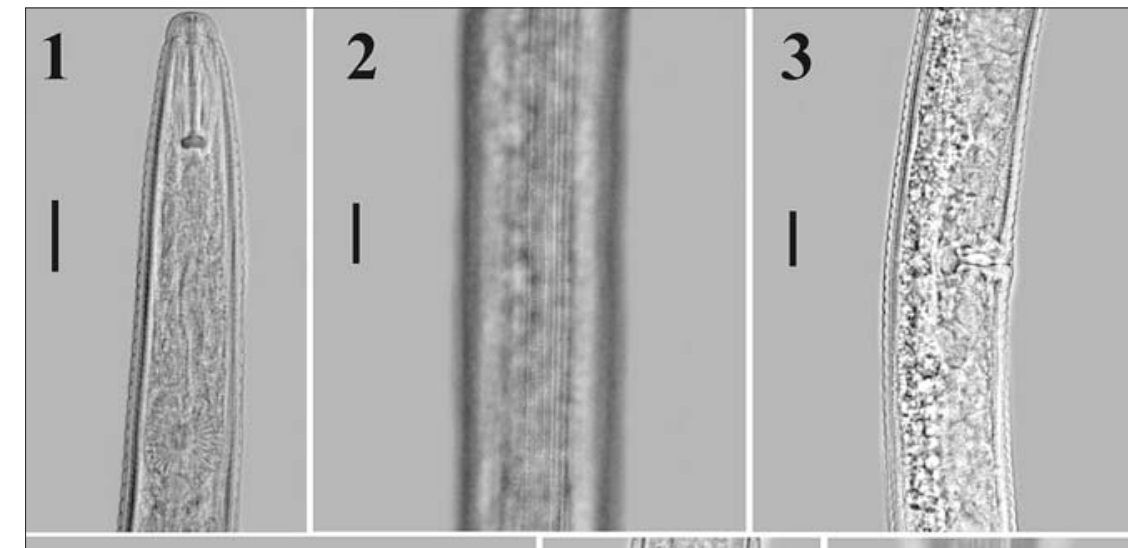

4

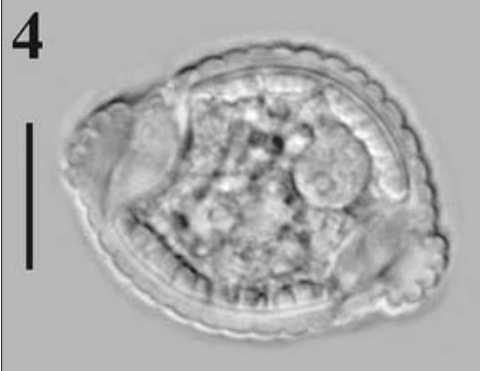

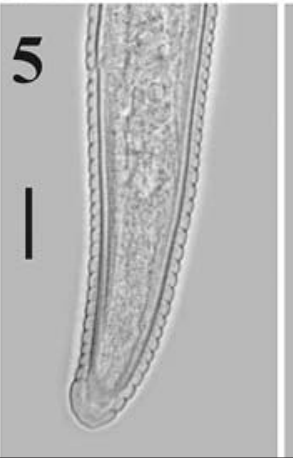

6

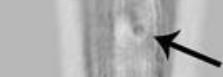

Fig. IV - Female of Scutylenchus rugosus. 1. Anterior end; 2. Lateral field at mid-body; 3. Vulval region; 4. Crosssection near mid-body; 5 . Tail; 6 . Tail showing phasmid. (Scale bars $=10 \mu \mathrm{m}$ ). 
Table 2 - Morphometrics of Psilenchus curcumerus collected from Iran.

\begin{tabular}{ccc}
\hline \hline \multicolumn{2}{c}{ Psilenchus curcumerus } & \multirow{2}{*}{ Character } \\
Males & Females & \\
\hline 4 & 20 & $\mathrm{n}$ \\
$831.0 \pm 98.5(702.0-911.0)$ & $1073.1 \pm 113.8(828.0-1179.0)$ & $\mathrm{L}$ \\
$43.9 \pm 1.0(42.9-44.9)$ & $44.4 \pm 2.0(41.3-46.8)$ & $\mathrm{a}$ \\
$5.4 \pm 0.6(4.8-6.1)$ & $7.4 \pm 0.4(6.5-8.5)$ & $\mathrm{b}$ \\
$6.1 \pm 0.6(5.5-7.0)$ & $7.5 \pm 0.4(6.7-8.0)$ & $\mathrm{c}$ \\
$8.5 \pm 0.4(8.0-9.0)$ & $8.8 \pm 0.8(7.9-10.0)$ & $\mathrm{c}^{\prime}$ \\
- & $46.6 \pm 1.8(44.0-49.6)$ & $\mathrm{V}$ \\
- & $54.0 \pm 1.8(50.7-56.9)$ & $\mathrm{V}^{\prime}$ \\
$11.3 \pm 0.3(11.0-11.7)$ & $13.9 \pm 0.7(12.7-14.6)$ & Stylet length \\
$33.9 \pm 0.9(33.0-34.8)$ & $26.2 \pm 3.4(23.0-34.9)$ & $\mathrm{m}$ \\
$5.9 \pm 0.5(5.3-6.5)$ & $6.1 \pm 0.7(5.3-7.2)$ & DGO \\
$56.0 \pm 1.5(54.6-58.1)$ & $56.4 \pm 1.3(54.8-59.0)$ & MB \\
$17.0 \pm 2.8(15.0-20.3)$ & $24.6 \pm 0.8(18.8-26.4)$ & Sody width \\
$105.0 \pm 7.8(94.0-112.0)$ & $117.1 \pm 6.3(109.0-127.5)$ & pore \\
- & $22.7 \pm 1.7(20.3-25.3)$ & Vulval body width \\
- & $441.2 \pm 18.2(416.9-467.8)$ & Vulva-anus \\
$12.4 \pm 0.6(11.7-13.0)$ & $16.1 \pm 1.7(14.0-18.7)$ & Anal body width \\
$136.0 \pm 11.5(122.1-150.5)$ & $148.0 \pm 10.8(130.7-162.2)$ & Tail length \\
- & $0.32 \pm 0.02(0.30-0.37)$ & T/VA \\
$22.6 \pm 3.0(18.2-25.0)$ & - & Spicule length \\
$6.2 \pm 0.6(5.5-7.0)$ & - & Gubernaculum \\
$49.0 \pm 1.5(47.1-50.2)$ & Bursa length
\end{tabular}

All measurements are in $\mu \mathrm{m}$ and in the form: mean \pm s.d. (range).

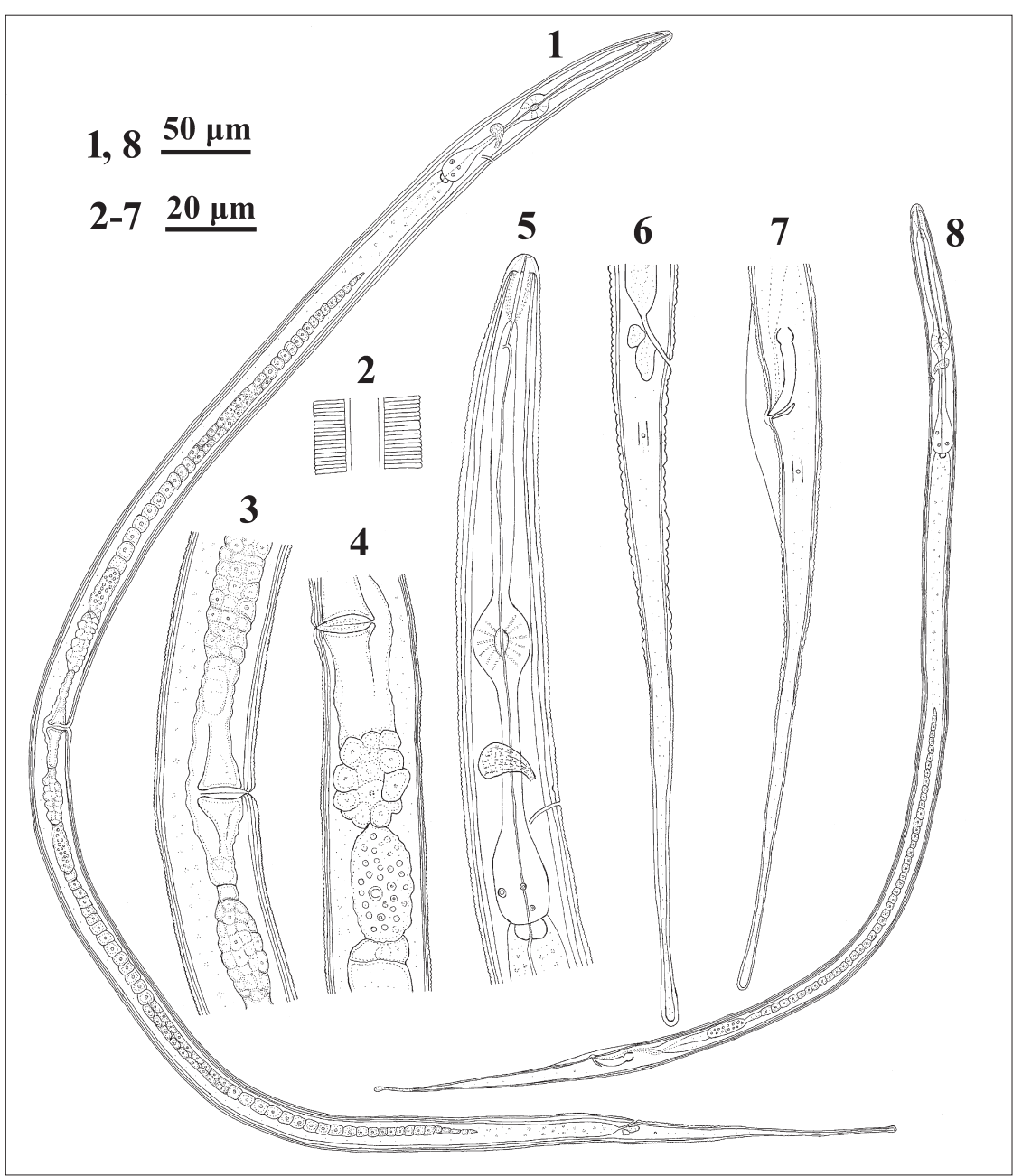

Fig. V - Psilenchus curcumerus. Female. 1. Entire body; 2. Lateral field at mid-body; 3, 4. Vulval region; 5. Anterior end; 6. Tail showing phasmid and Post-anal intestinal sac. Male. 7. Tail; 8. Entire body. 


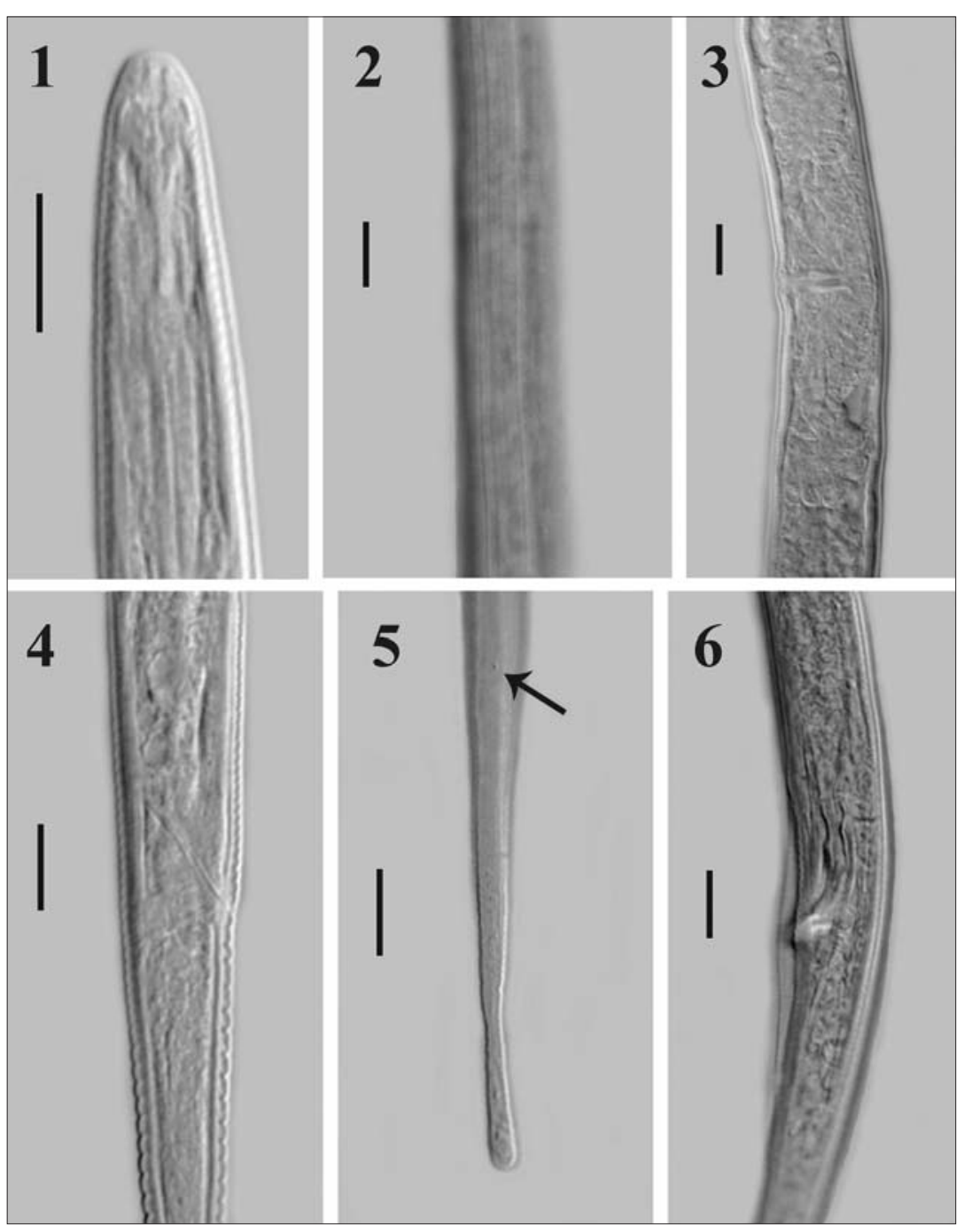

Fig. VI - Psilenchus curcumerus. Female. 1. Anterior end; 2. Lateral field at midbody; 3. Vulval region; 4. Anus and post rectal extension of intestine; 5 . Posterior end showing phasmid; Male. 6. Cloacal region showng bursa and spicule. (Scale bars $=10 \mu \mathrm{m})$.

outgroup taxon), yielded an alignment of $794 \mathrm{bp}$. The phylogenetic relationships among representatives of Tylenchidae, Psilenchidae, Merliniidae and additional tylenchid taxa, including the newly sequenced isolates are presented in Figure VII. The tree topologies of BI and ML analyses were congruent. Four major clades with high branch support values were distinguished in present phylogenetic tree. Clade I included representatives of the suborder Hoplolaimina Chizhov and Berezina, 1988; the new sequence of $P$. thornei grouped with another $P$. thornei sequence from Iran; clade II contained representatives of the family Merliniidae including the new sequences of $M$. microdorus and S. rugosus; clade III comprised of representatives of the family Psilenchidae where the new sequences for P. curcumerus is found; and clade IV consisted of species from the family Tylenchidae.

\section{DISCUSSION}

\section{REMARKS}

\section{Merlinius microdorus}

Number of tail annuli in the Iranian population is slightly higher than that given in the original description (41-64 vs 32-56), although this type of variation has already been reported by GHADERI et al. (2014a).
The studied population of $M$. microdorus is very similar to $M$. brevidens (Allen, 1955) Siddiqi, 1970 in morphological and morphometric characters, but differs in it's arched and refractive basal ring of the head framework (distinctive for M. brevidens). Also, M. microdorus is close to M. nanus (Allen, 1955) Siddiqi, 1970 by having long female genital branches and relatively large phasmids, however, the latter species can be differentiate on the basis of the cuticular striation, larger number of tail annuli, and a slightly but visible lower head (GERAERT, 2011). On the other hand, there are variations on a number of morphological characters of M. microdorus as described by GERAERT (2011). Those include the incisures of the lateral field (basically with six incisures, often additional lines may appear; sometimes all lines look alike making the total number of incisures 6,8 or 10 ), head region (usually narrower than adjacent body, sometimes continuous or separated by shallow depression), tail terminus shape (which is smooth or variably striated) and the position of phasmids (near middle of tail or more posterior). In the present study, such variations were also observed in the population of M. microdorus.

\section{Scutylenchus rugosus}

Iranian population of $S$. rugosus is in morphological and morphometric agreement with the original description. The studied population of $S$. rugosus is very similar to 


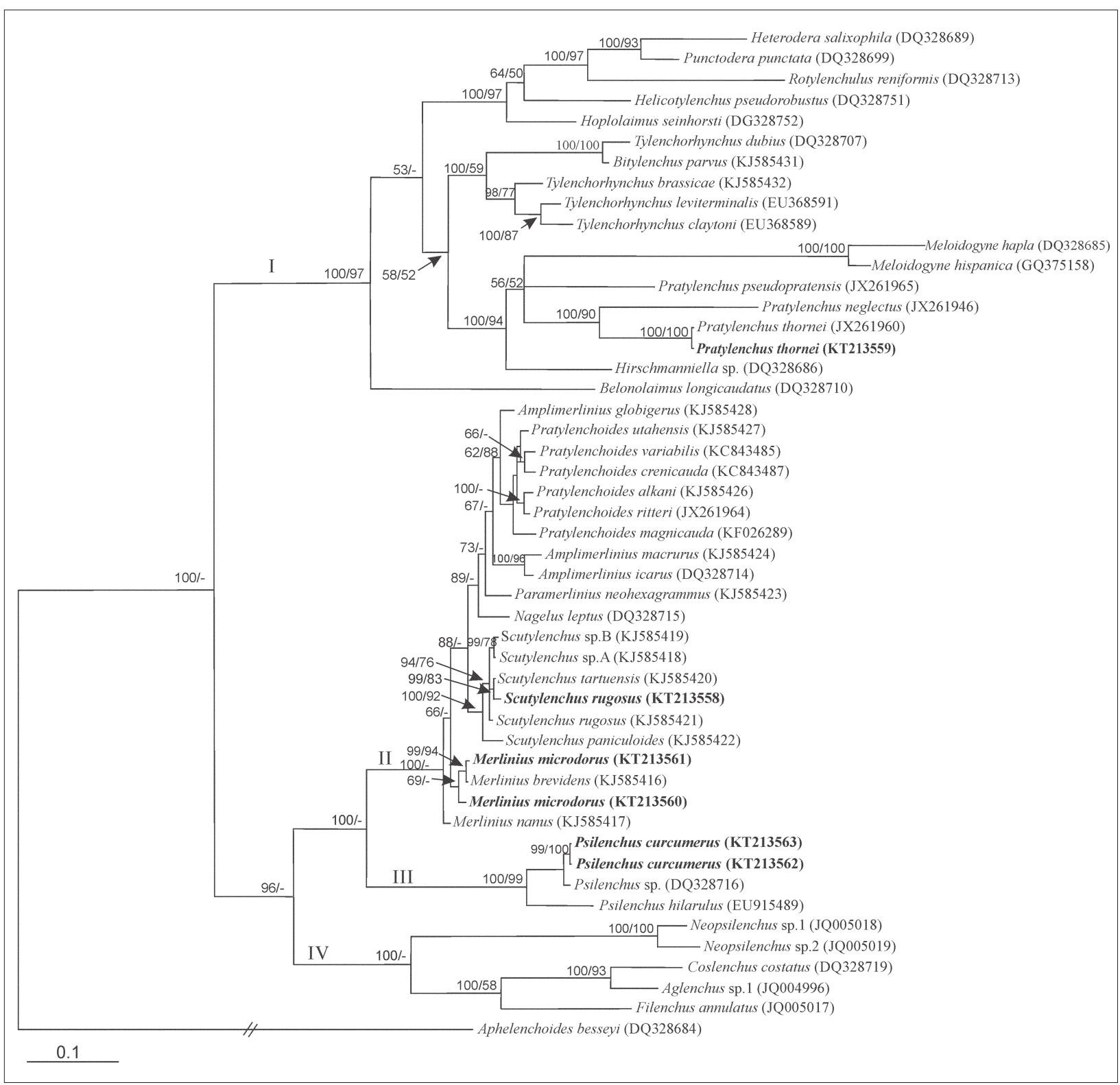

Fig. VII - Phylogenetic relationships within selected species of the tylenchid nematodes: Bayesian $50 \%$ majority rule consensus tree from two runs as inferred from analysis of the D2-D3 domains of the 28S rRNA gene under the GTR $+\mathrm{G}+\mathrm{I}$ model. Posterior probabilities for $\mathrm{BI} /$ bootstraps for $\mathrm{ML}$ analyses equal to or more than $50 \%$ are given for appropriate clades in the form: BPP/ML BS. New sequences are indicated in bold.

Scutylenchus quadrifer (Andrassy, 1954) Siddiqi, 1979 in morphological and morphometric characters, but the range of ratio $c^{\prime}$ is slightly higher (2.7-3.3 vs 1.6-2.7), spermatheca are without sperm ( $v s$ filled with sperm) and the number of tail annuli is slightly higher (23-35 vs 17-27). Also, it is close to Scutylenchus tartuensis (Krall, 1959) Siddiqi, 1979 but differs in it's arched and refractive basal ring of the head framework (cephalic skeleton with refractive in S. tartuensis) and spermatheca are without sperm (vs filled with sperm).

\section{Psilenchus curcumerus}

This species was originally described by RAHAMAN et al. (1994) from India. The general morphology of the Iranian population closely resembles that given in the original description. However, the dorsal gland orifice (DGO) position shows a wider range (5.3-7.2 vs 1.5-3.0 $\mu \mathrm{m})$, ratio a is slightly lower (41-47 vs 48-55), spicule and gubernaculum lengths are shorter (18.2-25 vs 27-30 $\mu \mathrm{m}$ and 5.5-7.0 $v s$ 10.5$12 \mu \mathrm{m}$ respectively). These differences can be attributed to the intraspecific variation due to geographical differences. PANAHANDEH et al. (2014) reported the same species from the rhizosphere of alfalfa in north-western Iran. It seems that the two populations from north-western and south-western Iran are very similar. The DGO length in north-western population is $5-6 \mu \mathrm{m}$, the range of ratio a is $40.2-52.5$, spicule and gubernaculum length is $20-25 \mu \mathrm{m}$ and $7-10 \mu \mathrm{m}$ respectively. This species is mainly characterized by having a smooth head region, 12-14 $\mu \mathrm{m}$ stylet length, post-rectal sac and filiform tail with a clavate terminus.

\section{MOLECULAR PHYLOGENETIC ANALYSES}

Phylogenetic relationships among tylenchid nematodes in this present are mostly congruent with those published by SUBBOTIN et al. (2006) and GHADERI et al. (2014b) using 28S 
rRNA gene data. The BI analysis showed that Merliniidae and Psilenchidae are reciprocally monophyletic with high support (100), however, this relationship is not supported in the ML analysis. This result is congruent with previous studies focusing on the tylenchids (SUBBOTIN et al., 2006; PALOMARES-Rius et al., 2009; CARTA et al., 2010; GHADERI et al., 2014b). The present study also indicated that Psilenchidae and Tylenchidae form two separate clades. Similar results have also been shown by SuBBotin et al. (2006) and PALOMARES-Rius et al. (2009). These results do not support the synonymy of Psilenchinae with the Boleodorinae (sensu Geraert \& Raski, 1987 and GERAERT, 2008). The placement of Psilenchus under Boleodorinae (sensu MAGGENTI et al., 1987) is also not supported by the molecular analyses. In this sense, this study provides additional evidence for the taxonomic framework proposed by SIDDIQI $(1986,2000)$ and RYSS (1993), which treated Psilenchus in a separate family, (Psilenchidae) other than Tylenchidae.

Four Psilenchus sequences were grouped in the clade III with high support $(B I=100, M L=99)$. Previous studies on $P$. curcumerus were only based on morphology and morphometrics. This is the first study including molecular data for this species. There were no nucleotide differences between two sequences of $P$. curcumerus in this study. Sequence divergence between $P$. curcumerus with $P$. hilarulus, sister taxa in the phylogenetic tree was $64 \mathrm{bp}$.

Two Merlinius species (M. brevidens and M. microdorus) are very closely related in the tree. This is the first molecular study of $M$. microdorus. There were only two records in GenBank for sequences of D2-D3 expansion segments of 28S rRNA gene for the genus Merlinius. Sequence divergence between $M$. microdorus with $M$. brevidens and $M$. nanus were 1-10 and 14-17 bp respectively. Thus, in order to clarify the relationships among $M$. brevidens, $M$. microdorus and the quantity of intraspecific variation, a more comprehensive phylogenetic study is needed using more samples of $M$. microdorus and $M$. brevidens from a wide geographical and ecological origin. Sequence divergence within M. microdorus (KT213560 and KT213561) was 8 bp. The emergence of this situation is probably due to high intraspecific variation in this species.

ANDERSON (1977) and STURHAN (2012) considered the genus Scutylenchus as a junior synonym of Merlinius or Geocenamus, respectively; however, SIDDIQI $(1979,2000)$ revalidated Scutylenchus. In the present study, all six sequences of Scutylenchus species have formed a monophyletic group, thus supporting the views of SIDDIQI $(1979,2000)$ on Scutylenchus as a distinct genus. Sequence divergence between $S$. rugosus and the five additional sequences of Scutylenchus from GenBank ranged from 4-23 bp. There was only one record in GenBank for sequence of D2-D3 expansion segments of 28S rRNA gene for $S$. rugosus and one record from $S$. tartuensis. Sequence divergence between $S$. rugosus isolate from this study with S. rugosus and S. tartuensis from GenBank were 8 and $4 \mathrm{bp}$, respectively. The studied population of $S$. rugosus is sister to $S$. tartuensis in the tree. This close phylogenetic relationship could be confirmed with close morphology and morphometrics too (cephalic framework in $S$. tartuensis is with refractive). Also, intraspecific variation is probably interfering. Thus more molecular evidence is needed to explain why $S$. rugosus from south-western Iran is more closely related to $S$. tartuensis than to another sequence representing a different population of $S$. rugosus in our phylogenetic analyses.
In a study by CARTA et al. (2010) based on 18S rRNA gene, two population of $S$. quadrifer (Andrássy, 1954) Siddiqi, 1979 demonstrated as much or greater genetic distance between them than among three related species of Merlinius. Also, sequence variation within studied Scutylenchus species by GHADERI et al. (2014b) ranged from 2-21 bp. In order to clarify the relationships among Merlinius and Scutylenchus species and the lack of monophyly at the species level for these two genera, a more comprehensive phylogenetic study is needed, in particular with a better taxon sampling geographic representation.

\section{ACKNOWLEDGMENTS}

We are grateful to Dr. Majid Pedram for his help and comments on phylogenetic analyses and Dr. Reza Ghaderi for help with identification of M. microdorus and S. rugosus species. We are also grateful to Prof. Dr. Sergei A. Subbotin for his valuable comments on phylogenetic relationships among M. microdorus and S. rugosus species.

\section{REFERENCES}

ANDERSON V.R., 1977 - Additional diagnostic characters and relationships of Merlinius laminatus (Wu, 1969) Siddiqi, 1970 (Nematoda: Merliniinae). - Can. J. Zool., 55: 1923-1926.

Bert W., Claeys M., Borgonie G., 2006 - The comparative cellular architecture of the female gonoduct among Tylenchoidea (Nematoda: Tylenchina). - J. Nematol., 38: 362-375.

Bert W., Leliaert F., Vierstraete A., Vanfleteren J., Borgonie G., 2008 - Molecular phylogeny of the Tylenchina and evolution of the female gonoduct (Nematoda: Rhabditida). - Mol. Phylogene. Evol., 48: 728-744.

Carta L.K., Skantar A.M., Handoo Z.A., 2010 Molecular rDNA phylogeny of Telotylenchidae Siddiqi, 1960 and evaluation of tail termini. - J. Nematol., 42: 359-369.

Chizhov V.N., Berezina N.V., 1988 - Structure and evolution of the genital system in female nematodes of the order Tylenchida. - Zool. Zh., 67: 485-494.

DE GRISSE A.T., 1969 - Redescription and modification of some techniques used in the study of nematodes phytoparasitaires. - Meded. Rijks. Landb. Wetensch. Gent, 34: 351-369.

GERAERT E., 1966 - On some Tylenchidae and Neotylenchidae from Belgium with the description of a new species, Tylenchorhynchus microdorus. Nematologica, 12: 409-416.

Geraert E., 2008 - The Tylenchidae of the world. Identification of the family Tylenchidae (Nematoda). Ghent, Belgium, Academia Press., 530 pp.

GeraerT E., 2011 - The Dolichodoridae of the world. Identification of the family Dolichodoridae. Ghent, Belgium, Academia Press., 520 pp.

GERAERT E., RASKI D.J., 1987 - A reappraisal of Tylenchina (Nemata). 3. The family Tylenchidae Orley, 1880. - Revue de Nematologie, 10: 143-161.

Ghaderi R., Karegar A., Niknam G., 2014a - An updated and annotated checklist of the Dolichodoridae (Nematoda: Tylenchoidea) of Iran. - Zootaxa, 3784: 445468.

Ghaderi R., Karegar A., Niknam G., Subbotin, S.A., 
2014b - Phylogenetic relationships of Telotylenchidae Siddiqi, 1960 and Merliniidae Siddiqi, 1971 (Nematoda: Tylenchida) from Iran, as inferred from the analysis of the D2D3 expansion fragments of 28S rRNA gene sequences. - Nematology, 16: 863-877.

Holterman M., Van Der Wurff A., Van Den Elsen S., Van Megen H., Bongers T., Holovachov O., BaKker J., HELDER J., 2006 - Phylum-wide analysis of SSU rDNA reveals deep phylogenetic relationships among nematodes and accelerated evolution toward crown clades. - Mol. Biol. Evol., 23: 1792-1800.

Holterman M., Karssen G., Van Den Elsen S., Van Megen H., BAKKer J., Helder J., 2009 - Small subunit rDNA-based phylogeny of the Tylenchida sheds light on relationships among some high-impact plant-parasitic nematodes and the evolution of plant feeding. Phytopathology, 99: 227-235.

Huson D., Scornavacca C., 2012 - Dendroscope 3: An interactive tool for rooted phylogenetic trees and networks. - Syst. Biol., 1-7.

JENKINS W.R., 1964 - A rapid centrifugal flotation technique for separating nematodes from soil. - Pl. Dis. Reptr., 48: 692.

LARget B., Simon D.L., 1999 - Markov chain Monte Carlo algorithms for the Bayesian analysis of phylogenetic trees. - Mol. Biol. Evol., 16: 750-759.

Luc M., Maggenti A.R., Fortuner R., Raski D.J., GERAERT E., 1987 - A reappraisal of Tylenchina (Nemata). 1. For a new approach to the taxonomy of Tylenchina. - Revue de Nematologie, 10: 127-134.

Maggenti A.R., Luc M., Raski D.J., Fortuner R., Geraert E., 1987 - A reappraisal of Tylenchina (Nemata). 2. Classification of the suborder Tylenchina (Nemata: Diplogasteria). - Revue de Nématologie, 10: 135-142.

NunN G.B., 1992 - Nematode molecular evolution. PhD Thesis, University of Nottingham, Nottingham, U.K., 192 pp.

NYLANDER J.A.A., 2004 - MrModeltest v2. Evolutionary Biology Centre, Uppsala University. Available from: http://www.ebc.uu.se/ systzoo/staff/nylander.html (accessed 14 April 2014).

Palomares-Rius J.E., Subbotin S.A., Liébanas G., Landa B.B., Castillo P., 2009 - Eutylenchus excretorius Ebsary and Eveleigh, 1981 (Nematoda: Tylodorinae) from Spain with approaches to molecular phylogeny of related genera. - Nematology, 11: 343-354.

Panahandeh Y., Pourjam E., Pedram M., 2014 - Four new
Tylenchids (Tylenchina: Nematoda) for nematode fauna of Iran. - J. Agri. Sci. Tech., 16: 461-477.

Pedram M., Pourjam E., Ye W., Atighi M.R., Robbins R.T., RYss A., 2011 - Description of Bursaphelenchus mazandaranense sp. n. (Nematoda: Parasitaphelenchidae) from Iran. - Russ. J. Nematol., 19: 121-129.

Rahaman P.F., AhMAD I., JAIRAJPURI M., 1994 - One new and two known species of the family Tylenchidae. - Indian J. Nematol., 24: 62-68.

Ronquist F., Huelsenbeck J.P., 2003 - MrBayes 3: Bayesian phylogenetic inference under mixed models. Bioinformatics, 19: 1572-1574.

RYSS A.Y., 1993 - Phylogeny of the order Tylenchida (Nematoda). - Russ. J. Nematol., 1: 74-95.

SIDDIQI M.R., 1963 - On the identity of Belonolaimus hastulatus Colbran, 1960 and Tylenchorhynchus indicus Siddiqi, 1961. - Current Science, 32: 550- 551.

SIDDIQI M.R., 1970 - On the plant-parasitic nematode genera Merlinius gen. $n$. and Tylenchorhynchus Cobb and the classification of the families Dolichodoridae and Belonolaimidae n. rank. - Proc. Helminth. Soc. Wash., 37: 68-77.

SIDDIQI M.R., 1979 - Taxonomy of the plant nematode subfamily Merliniinae Siddiqi, 1970, with descriptions of Merlinius processus n. sp., M. loofi $n$. sp. and Amplimerlinius globigerus $n$. $s p$. from Europe. - Syst. Parasitol., 1: 43-59.

SIDDIQI M.R., 1986 - Tylenchida: parasites of plants and insects. CABI Publishing, Wallingford, UK, 645 pp.

SIDDIQI M.R., 2000 - Tylenchida: parasites of plants and insects. CABI Publishing, Wallingford, UK, 833 pp.

Silvestro D., MichalaK I., 2012 - RaxmlGUI: a graphical front-end for RAx ML. - Org. Divers. Evol., 12: 335-337.

STURHAN D., 2012 - Contribution to a revision of the family Merliniidae Ryss, 1998, with proposal of Pratylenchoidinae subfam. n., Paramerlinius gen. n., Macrotylenchus gen. $n$. and description of M. hylophilus sp. n. (Tylenchida). - J. Nematode Morphol. Syst., 15: 127-147.

Sturhan D., RAHI M., 1996 - Phasmid-like structures in Anguinidae (Nematoda: Tylenchida). - Fund. Appl. Nematol., 19: 185-188.

Subbotin S.A., Sturhan D., Chizhov V.N., Vovlas, N., BALdwin J.G., 2006 - Phylogenetic analysis of Tylenchida Thorne, 1949 as inferred from D2 and D3 expansion fragments of the $28 S$ rRNA gene sequences. Nematology, 8: 455-474. 